Marquette University

e-Publications@Marquette

Psychology Faculty Research and Publications

Psychology, Department of

$1-1-2004$

fMRI of Healthy Older Adults During Stroop Interference

Scott Aaron Langenecker

University of Michigan - Ann Arbor

Kristy A. Nielson

Marquette University, kristy.nielson@marquette.edu

Stephen M. Rao

Schey Center for Cognitive Neuroimaging

Accepted version. NeuroImage, Vol. 21, No. 1 (January 2004): 192-200. DOI. (C) 2003 Elsevier Inc. Used with permission. 


\title{
fMRI of Healthy Older Adults During Stroop Interference
}

\author{
Scott A. Langenecker \\ Department of Psychology and the Integrative Neuroscience \\ Research Center, Marquette University, \\ Milwaukee, WI \\ Kristy A. Nielson \\ Department of Psychology and the Integrative Neuroscience \\ Research Center, Marquette University, \\ Foley Center for Aging and Development, Department of \\ Psychiatry and Behavioral Medicine, \\ Medical College of Wisconsin, \\ Milwaukee, WI \\ Stephen M. Rao
}

Department of Neurology, Section on Neuropsychology,

Medical College of Wisconsin,

Milwaukee, WI

Neurolmage, Vol 21, No. 1 (January 2004): pg. 192-200. DOI. This article is $\subset$ Elsevier and permission has been granted for this version to appear in e-Publications@Marquette. Elsevier does not grant permission for this article to be further copied/distributed or hosted elsewhere without the express permission from Elsevier. 


\begin{abstract}
The Stroop interference effect, caused by difficulty inhibiting overlearned word reading, is often more pronounced in older adults. This has been proposed to be due to declines in inhibitory control and frontal lobe functions with aging. Initial neuroimaging studies of inhibitory control show that older adults have enhanced activation in multiple frontal areas, particularly in inferior frontal gyrus, indicative of recruitment to aid with performance of the task. The current study compared 13 younger and 13 older adults, all healthy and well educated, who completed a Stroop test during functional magnetic resonance imaging. Younger adults were more accurate across conditions, and both groups were slower and less accurate during the interference condition. The groups exhibited comparable activation regions, but older adults exhibited greater activation in numerous frontal areas, including the left inferior frontal gyrus. The results support the recruitment construct and suggest, along with previous research, that the inferior frontal gyrus is important for successful inhibition.
\end{abstract}

Keywords: fMRI, Stroop interference, Inferior frontal gyrus

The Stroop Color Word Interference test (Stroop, 1935) is an oft-used task thought to measure several cognitive constructs including sustained attention, interference, and inhibition (Barkley, 1997; Zajano and Gorman, 1986). The Stroop test consists of color name words printed in both congruent colors (i.e., red printed in red ink) and incongruent colors (i.e., red printed in blue ink). Naming the color of the ink when the meaning of the word is an incongruent color results in a delayed response time, known as Stroop interference. This cost in response time is thought to occur because of the interference between the overlearned, "automatic," reading response and the required color-naming strategy (Kahneman and Chajczyk, 1983).

The Stroop test has also been used to examine purported agerelated declines in inhibitory control because it produces interference from two competing streams of information, from which individuals must inhibit processing of one to select and respond to the other (e.g., Hasher and Zacks, 1988; but see Kramer et al., 1994). Typically, the Stroop effect is greater for older adults (Logan, 1980), which is believed to be due to a decline in the ability to inhibit processing of one of the competing inputs (Cohen et al., 1984; Kahneman and Chajczyk, 1983). However, interference and inhibition are not synonymous. Rather, interference is a measurable effect of cognitive load, while inhibition is a neural process of attentional selection that can serve to reduce interference. The specific inhibitory mechanism that might be implicated in increased Stroop interference is that of

Neurolmage, Vol 21, No. 1 (January 2004): pg. 192-200. DOI. This article is (C Elsevier and permission has been granted for this version to appear in e-Publications@Marquette. Elsevier does not grant permission for this article to be further copied/distributed or hosted elsewhere without the express permission from Elsevier. 
"restraint inhibitory control," or the ability to restrain prepotent stimuli from "seizing control of thought and action effectors (Hasher et al., 1999 , p. 654)." A number of studies support the inhibitory theory of aging and suggest that intact frontal lobes are necessary for effective inhibitory control (cf. Kramer et al., 1994).

Clinical and recent neuroimaging studies implicate both medial and lateral frontal cortex as mediating Stroop interference. For example, lesion studies show increased Stroop interference with frontal lesions generally (Vendrell et al., 1995), and dorsolateral prefrontal lesions specifically (Perret, 1974), particularly when the damage was to the right side (Vendrell et al., 1995). A study of multiple sclerosis participants further demonstrated that right medial frontal lesions were significantly associated with Stroop interference, and these taken with left parietal lesions accounted for $65 \%$ of Stroop interference variance (Pujol et al., 2001). Recent neuroimaging studies in healthy young adults show activation in right anterior cingulate and left middle and inferior frontal gyri during Stroop interference (Banich et al., 2000; Bench et al., 1993; Brown et al., 1999; Carter et al., 1995; George et al., 1994, 1997; Mead et al., 2002; Pardo et al., 1990; Taylor et al., 1997).

Neuroimaging studies of older adults have begun to appear over the past decade, yet still few studies exist. Most of the available studies have varied widely in method, and most have used perceptual or memory paradigms. Some report that while older adults exhibit activation in comparable areas as younger adults, the extent of activation in these areas is reduced in older adults (e.g., Grady et al., 1995; Rypma and D'Esposito, 2000). However, quite a few studies report essentially no differences in activation between young and healthy older adults, except with additional regions of activation in older adults, which are frequently in contralateral and prefrontal areas (cf. Cabeza, 2002; e.g., Cabeza et al., 1997; DiGirolamo et al., 2001; Grady et al., 1994, 1995; Madden et al., 1997; Nielson et al., 2002). A number of the imaging studies also report differences between younger and older adults in the inferior parietal lobule, the dorsomedial nucleus of the thalamus, and the occipital lobe (Buckner et al., 2000; DiGirolamo et al., 2001; Grady et al., 1994, 1995; Huettel et al., 2001; Madden and Hoffman, 1997; Madden et al., 1999; Nielson et al., 2002).

Neurolmage, Vol 21, No. 1 (January 2004): pg. 192-200. DOI. This article is (C) Elsevier and permission has been granted for this version to appear in e-Publications@Marquette. Elsevier does not grant permission for this article to be further copied/distributed or hosted elsewhere without the express permission from Elsevier. 
Some recent studies have directly addressed inhibitory control in older adults. Electroencephalography (EEG) was used by West and Bell (1997) showing age-related differences in EEG activation during Stroop interference in medial and lateral frontal regions and parietal regions. A recent study used functional magnetic resonance imaging (fMRI) with a go/no-go inhibition task (Nielson et al., 2002). It showed that healthy, well-educated older and young adults had comparable activation in most regions, but that older adults had significantly greater activation in multiple predominantly frontal regions, including the left inferior frontal gyrus. Inferior frontal gyri have been implicated in inhibition in several neuroimaging studies (e.g., Garavan et al., 1999; Konishi et al., 1998a,b, 1999). In addition, older participants who had more difficulty with inhibition had more activation in these regions during "successful" inhibition than did those who were better at the task, suggesting that increased activation by elders in these regions is compensatory. In contrast, L onides et al. (2000) reported greater left prefrontal activation in younger adults when comparing high and low interference conditions of a verbal working memory recognition task during positron emission computed tomography (PET). This task was actually quite different from the go/no-go task used by Nielson et al. (2002), and from a Stroop task, which could be responsible for the differences in activation patterns. Another fMRI study used the Stroop test (Milham et al., in press) and reported activation differences between young and older adults predominantly in frontal regions, but the differences occurred in both congruent and incongruent conditions. In addition, younger adults had greater activation than older adults during Stroop interference in left middle frontal gyrus, anterior cingulate, and superior parietal lobule, while older adults had greater activation than young adults in bilateral inferior frontal gyri. The findings of greater young than older adults activation are consistent with some studies (e.g., Grady et al., 1995; Jonides et al., 2000; Rypma and D'Esposito, 2000), but inconsistent with others (e.g., Cabeza et al., 1997; Grady et al., 1994; Madden et al., 1997; Nielson et al., 2002). Moreover, the inferior frontal gyrus findings are consistent with previous reports that inferior frontal gyri are important for inhibition and are more active in older adults than young adults during inhibition (e.g., Nielson et al., 2002). Importantly, there was a trend but not a significant difference behaviorally in Stroop interference between young and older subjects in the study of

Neurolmage, Vol 21, No. 1 (January 2004): pg. 192-200. DOI. This article is (C) Elsevier and permission has been granted for this version to appear in e-Publications@Marquette. Elsevier does not grant permission for this article to be further copied/distributed or hosted elsewhere without the express permission from Elsevier. 
Milham et al. (in press), which may have contributed to discrepancies with previous studies where older adults exhibited significantly more difficulty with inhibition (e.g., Nielson et al., 2002).

The current study was conducted with fMRI to further evaluate the neural mechanisms of Stroop interference in older adults. It was expected that older adults would exhibit more frontal activation, particularly in the left inferior frontal gyrus (Milham et al., in press; Nielson et al., 2002), and that older adults would exhibit more extraneous areas of activation during Stroop interference compared to younger adults (e.g., Grady et al., 1994; Madden et al., 1997; Nielson et al., 2002). Milham et al. (in press) also reported reduced activation in older adults in dorsolateral prefrontal regions compared to young adults, but this finding conflicts with some reports, including our own. As such, it was difficult to predict whether this would occur.

\section{Methods}

\section{Participants}

Thirteen older adults were recruited through a retirement association and a university. The young adult data were a subset of those used by Mead et al. (2002), where participants were recruited through a university and newspaper advertisements. Each person was paid US\$10 per hour. Demographic information is depicted in Table 1. All participants were predominantly right-handed as measured by the Edinburgh Handedness Inventory (Oldfield, 1971), and were free of current or past neurological, health, or psychological illnesses that might affect cognitive functioning or fMRI signal. Older participants were screened using the Mini-Mental State Exam (Folstein et al., 1975, score greater than 26), and the Geriatric Depression Scale (Sheikh and Yesavage, 1986, score less than 10). Most of the older participants were also given a 3-h neuropsychological battery that was administered on a separate occasion, but the data are not presented here. Participants provided informed consent according to approved institutional guidelines.

Neurolmage, Vol 21, No. 1 (January 2004): pg. 192-200. DOI. This article is (C) Elsevier and permission has been granted for this version to appear in e-Publications@Marquette. Elsevier does not grant permission for this article to be further copied/distributed or hosted elsewhere without the express permission from Elsevier. 
NOT THE PUBLISHED VERSION; this is the author's final, peer-reviewed manuscript. The published version may be accessed by following the link in the citation at the bottom of the page.

Table 1. Demographic data

\begin{tabular}{|c|c|c|c|c|}
\hline & \multicolumn{2}{|c|}{ Older adults } & \multicolumn{2}{|c|}{ Younger adults } \\
\hline & M & SD & & SD \\
\hline Age (years) & 71.1 & 5.4 & 26.3 & 5.5 \\
\hline Education (years) & 17.8 & 2.8 & 17.2 & 3.3 \\
\hline GDS score & 1.62 & 2.81 & & \\
\hline MMSE score & 28.4 & 1.56 & & \\
\hline Gender & five male & t females & six $\mathrm{m}$ & females \\
\hline
\end{tabular}

\section{Task and procedures}

\section{Stroop Color-Word Interference test}

A series of three consecutive activation conditions preceded and followed by a baseline rest period were completed by each participant in each of six trials of imaging, presented in counterbalanced order. One older participant who was included in the comparisons completed only five of the six experimental trials (with prorated behavioral data). Stimuli consisted of words printed in one of four colors (red, blue, green, or yellow) to form three conditions. The Congruent condition consisted of color words printed in the same color as the semantic meaning of the word (e.g., "blue" in blue ink). The Neutral condition consisted of words printed in a color that was irrelevant to the semantic meaning of the word (e.g., "jacket" printed in blue ink). The Incongruent condition consisted of color words printed in a color different from the meaning of the word (e.g., "red" printed in blue ink). Stimuli were presented centrally with one trial every 2 s (1250 ms on; $750 \mathrm{~ms}$ off). For each condition, the participant was to respond to the printed color of the stimulus, ignoring the word itself, by pressing one of four buttons corresponding to the four possible print colors, using digits 2 through 5 of the dominant (right hand). A model representing the various response possibilities and their representative locations on the keypad (i.e., digit 2 is red, digit 3 is yellow) remained at the bottom of the screen throughout the experimental trials.

Neurolmage, Vol 21, No. 1 (January 2004): pg. 192-200. DOI. This article is (c) Elsevier and permission has been granted for this version to appear in e-Publications@Marquette. Elsevier does not grant permission for this article to be further copied/distributed or hosted elsewhere without the express permission from Elsevier. 
NOT THE PUBLISHED VERSION; this is the author's final, peer-reviewed manuscript. The published version may be accessed by following the link in the citation at the bottom of the page.

\section{Apparatus}

A 1.5-T GE Signa scanner equipped with a $30.5-\mathrm{cm}$ i.d. threeaxis local gradient coil and an endcapped quadrature birdcage radiofrequency head-coil were used to obtain the functional and anatomical images (Wong et al., 1992a, b). AFNI (Cox, 1996) was used for all functional analyses. Two Sharp laptop computers, an Epson projector, and prism glasses (and correction lenses, as needed) were used to administer stimuli (via back projection to a vertical screen at participants' feet) and collect response data.

\section{Imaging procedure}

Contiguous 6-7 mm sagittal slices covering the entire brain were collected using a blipped gradient-echo, echoplanar pulse sequence $(\mathrm{TE}=40 \mathrm{~ms}, \mathrm{TR}=4000 \mathrm{~ms} ; \mathrm{FOV} 24 ; 64 \times 64$ matrix; 3.75 $\times 3.75$ in-plane resolution) on a 1.5-T GE Signa scanner. As they were originally a part of separate research protocols, the two groups had slightly different image acquisition parameters (young adults $=22,6$ $\mathrm{mm}$ sagittal slices; older adults $=19,7 \mathrm{~mm}$ sagittal slices), which could have resulted in slightly greater signal in younger adults, but were expected to be negligible given the multiple subtraction design. High-resolution spoiled GRASS images were acquired before functional imaging to allow subsequent anatomical localization of functional activation. Foam padding was used to limit head movements.

In this blocked design study, 104 images were collected for each of the six series. Each series consisted of four cycles of rest and activation with a 24-s rest period at the beginning and ending of each series and activation periods consisting of three consecutive 24-s (12trial) epochs, one for each condition. The order of presentation of the three conditions was fully counterbalanced within participants.

\section{fMRI analyses}

Individual analyses

A difference image was created for each of the three conditions by subtracting the average rest image $(R)$ from the corresponding average activation condition image. In all, 24 difference images (4

Neurolmage, Vol 21, No. 1 (January 2004): pg. 192-200. DOI. This article is (C) Elsevier and permission has been granted for this version to appear in e-Publications@Marquette. Elsevier does not grant permission for this article to be further copied/distributed or hosted elsewhere without the express permission from Elsevier. 
cycles/image series $\times 6$ image series/session) were generated per participant for each of the three experimental conditions. Mean difference values were then compared on a voxel-by-voxel basis between activation conditions using t tests for correlated samples. Statistical Parametric Maps (SPMs) were created using t deviates for each comparison between conditions (e.g., (I-R) - (N-R)) for each participant. This subtraction analysis was used to control for the motoric and perceptual aspects of responding while emphasizing the differences in activation when interference was present (Incongruent) versus not present (Neutral, Congruent). A comparison between the two non-interference conditions $((\mathrm{C}-\mathrm{R})-(\mathrm{N}-\mathrm{R}))$ was conducted as a control for the interference analyses. The SPMs from the I-N, I-C, and $\mathrm{C}-\mathrm{N}$ comparisons were combined to create three functional activation maps of the brain for each participant.

\section{Group analyses}

The I- $\mathrm{N}$ and I-C statistical maps for each participant were subsequently used for final analyses as these were thought to best capture the increased interference in the Incongruent condition. The C$\mathrm{N}$ comparison was also analyzed as an experimental control. The SPMS for the two comparisons were then matched to previously acquired anatomical images and converted to $1 \mathrm{~mm}^{3}$ voxels. The resulting maps were transformed into standard stereotaxic space (Talairach and Tournoux, 1988). A 4.2 full width-at-half-maximum isotropic Gaussian filter was used to control for normal variations in anatomy and physiology across participants.

Older and younger groups were then combined to form separate I-C, I-N, and C-N group maps. Separate group analysis to create initial cluster threshold maps allows sensitivity to the separate contributions of each group to activation patterns. A threshold was then applied to the averaged t statistics to identify voxels in which differences in MR signal were unlikely to be due to chance. This was accomplished using a combined probability threshold that accounts for both the size of clusters and the degree of activation within those clusters. This procedure, described in detail elsewhere (Nielson et al., 2002; Ward et al., 1998), takes a size threshold, combined with a probability threshold for degree of activation to compute a size by activation threshold probability. A minimum cluster size of $109 \mathrm{~mm}^{3}$ combined

Neurolmage, Vol 21, No. 1 (January 2004): pg. 192-200. DOI. This article is (c) Elsevier and permission has been granted for this version to appear in e-Publications@Marquette. Elsevier does not grant permission for this article to be further copied/distributed or hosted elsewhere without the express permission from Elsevier. 
with a per cluster activation threshold probability threshold of $\mathrm{P}<$ $0.001(\mathrm{t}(12)=4.20)$ was used in comparing the SPM maps for I-C, I$\mathrm{N}$, and $\mathrm{C}-\mathrm{N}$ comparisons. This resulted in an experiment-wise error rate of 0.006 as each group was tested separately relative to the null hypothesis in each of three comparisons of interest. The resulting clusters, regions of significant activation in either subject group, were then combined into three separate cluster maps (I-C, I-N, C-N), which were used to extract averaged t statistics for each cluster for each participant to use for subsequent analyses. Individual t tests between groups were then conducted using the average t statistic for each cluster for each person from the three comparison conditions.

\section{Results}

\section{Behavioral analyses}

A $2 \times 3$ mixed factorial ANOVA was computed with Reaction Time as the dependent variable and Group (between-subjects) and Condition (within-subjects) as the independent variables. Older adults did not significantly differ from younger adults $(F(1,24)=0.64, P=$ $0.432)$, nor was there a significant interaction between Group and Condition $(F(2,48)=1.24, P=0.299)$. There was a significant main effect among the Conditions $(F(2,48)=38.78, P=0.0001)$, where reaction time was slower for the Incongruent condition than for the Congruent $(t(1,25)=-7.29, P=0.0001)$ and Neutral conditions $(t(1,25)=-5.86, P=0.0001)$, and Neutral stimuli produced slower responses than Congruent stimuli $(t(1,25)=-3.92, P=0.001)$. These results are depicted in Table 2.

Table 2. Behavioral data for the Stroop task

\begin{tabular}{|c|c|c|c|c|c|c|}
\hline & \multicolumn{2}{|r|}{ Neutral } & \multicolumn{2}{|c|}{ Congruent } & \multicolumn{2}{|c|}{ I ncongruent } \\
\hline & & SD & M & SD & M & SD \\
\hline \multicolumn{7}{|l|}{$\begin{array}{l}\text { RT (in } \\
\text { milliseconds) }\end{array}$} \\
\hline Older Adults & 763 & 97 & 733 & 133 & 851 & 115 \\
\hline Younger Adults & 751 & 107 & 693 & 111 & 799 & 134 \\
\hline $\mathrm{t}$ tests & $t(24)$ & $=-0.31, P=0.76$ & $\begin{array}{l}t(24)= \\
0.41\end{array}$ & $34, P=$ & $\begin{array}{l}\mathrm{t}(24)= \\
0.30\end{array}$ & $1.1, P=$ \\
\hline \multicolumn{7}{|l|}{ Errors (\%) } \\
\hline Older Adults & 13.3 & 8.7 & 12.6 & 8.6 & 16.6 & 10 \\
\hline Younger Adults & 3.7 & 2.9 & 2.3 & 2.0 & 4.9 & 5.2 \\
\hline
\end{tabular}

Neurolmage, Vol 21, No. 1 (January 2004): pg. 192-200. DOI. This article is (C) Elsevier and permission has been granted for this version to appear in e-Publications@Marquette. Elsevier does not grant permission for this article to be further copied/distributed or hosted elsewhere without the express permission from Elsevier. 
NOT THE PUBLISHED VERSION; this is the author's final, peer-reviewed manuscript. The published version may be accessed by following the link in the citation at the bottom of the page.

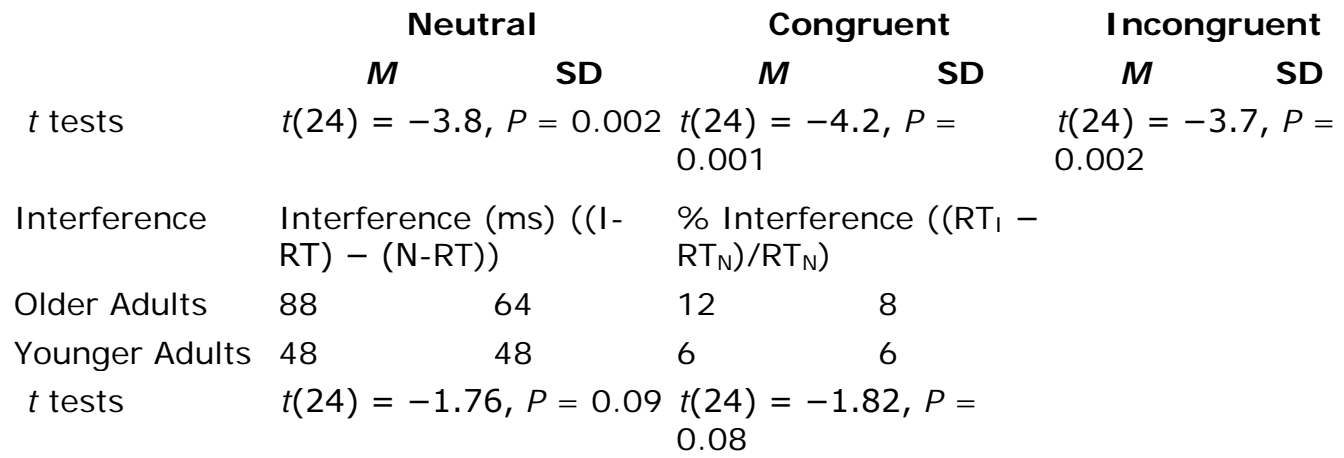

A second $2 \times 3$ mixed factorial ANOVA was computed with Percent Incorrect Responses as the dependent variable. The Group main effect was significant whereby older adults made significantly more errors than young adults $(F(1,24)=16.44, P=0.0001)$. There was also a significant main effect of Condition $(F(1,24)=9.77, P=$ $0.005)$, but the interaction between Group and Condition was not significant $(F(2,48)=1.12, P=0.335)$. Post hoc tests indicated that participants committed more errors for the Incongruent condition compared to the Congruent $(\mathrm{t}(1,25)=-4.06, \mathrm{P}=0.0001)$ and Neutral conditions $(t(1,25)=-3.06, P=0.005)$. There were no differences in errors between the Neutral and Congruent conditions $(t(1,25)=1.89$, $P=0.071$. These results are depicted in Table 2 . As a follow-up, a ratio score of percent errors was calculated (Percent Incongruent Errors/((Percent Congruent Errors + Percent Neutral Errors)/2)), which showed no difference between the groups and a small effect size $\left(F(1,24)=0.55, P=0.47\right.$, eta ${ }^{2}=0.022 ;$ Old $M=1.67, S D=1.5$, Young $M=1.36, S D=0.31$ ). Thus, the percentage of errors was higher overall in older adults, but it was not specific to a particular condition.

As a comparison with Milham et al. (in press), computations were made for the amount of interference $(I-R T)-(N-R T)$ and the percentage of interference $\left(\left(R T_{1}-R T_{N}\right) / R T_{N}\right.$; a control for generally slower reaction time in older adults). The amount of interference was not significantly different between groups, but there was a trend toward greater interference in older participants with a moderately large effect size $\left(F(1,24)=3.09, P=0.09\right.$, eta ${ }^{2}=0.114$; Older $M=$ $88 \mathrm{~ms}, \mathrm{SD}=64$; Young $M=48 \mathrm{~ms}, \mathrm{SD}=48$ ). The percentage of interference likewise was not significantly different but tended toward

Neurolmage, Vol 21, No. 1 (January 2004): pg. 192-200. DOI. This article is (C) Elsevier and permission has been granted for this version to appear in e-Publications@Marquette. Elsevier does not grant permission for this article to be further copied/distributed or hosted elsewhere without the express permission from Elsevier. 
greater interference in older adults $\left(\mathrm{F}(1,24)=3.33, \mathrm{P}=0.08\right.$, eta ${ }^{2}=$ 0.122 ; Older $M=12 \%(S D=8 \%)$, Young $M=6 \%(S D=6 \%)$ ).

\section{Functional results}

\section{C-N comparison}

The clusters of significant activation for either group are presented in Table 3. Two of the clusters, one in the left superior frontal gyrus and the other in the left middle temporal gyrus, had significantly greater activation for Older adults when compared to Young adults.

Table 3. Significant clusters for younger and older adults-congruent-neutral comparison

\begin{tabular}{|c|c|c|c|c|c|c|c|c|}
\hline Hemisphere/ Lobe & Location & BA & $\begin{array}{l}\text { Volume } \\
\left(\mathrm{mm}^{3}\right)\end{array}$ & $\mathbf{R L}$ & AP & IS & $\mathbf{t}$ & Result \\
\hline Right/ & & & & & & & & \\
\hline $\begin{array}{l}\text { Occipital } \\
\text { Left/ }\end{array}$ & Inf. O. Gyrus & 18 & 272 & 43 & -90 & -6 & -1.48 & 8 n.s. \\
\hline Frontal & $\begin{array}{l}\text { Superior F. } \\
\text { Gyrus }\end{array}$ & 11 & 116 & -15 & 58 & -10 & -5.06 & $6 \mathrm{O}>\mathrm{Y}$ \\
\hline Temporal & Mid. Temporal & 21 & 173 & -32 & & -29 & -4.0 & $\mathrm{O}>\mathrm{Y}$ \\
\hline Cerebellum & Posterior Lobe & & 188 & -3 & -67 & -28 & -1.77 & 7 n.s. \\
\hline
\end{tabular}

$\mathrm{BA}=$ Brodmann area, $\mathrm{RL}=$ right to left, $\mathrm{AP}=$ anterior to posterior, and $\mathrm{IS}=$ inferior to superior via Talairach and Tournoux (1988).

\section{I-C comparison}

Significant activation clusters for the I-C comparison are reported in Table 4. Older adults exhibited greater interference-based activation in 14 clusters compared to Young adults. Twelve of the clusters were in frontal regions; 9 were in the right frontal gyri, while the 2 significant left frontal clusters were in the inferior frontal gyrus. Older adults also had greater activation in the Congruent condition compared to younger adults in a cluster in the right medial frontal gyrus. Young adults produced no clusters significantly more active during the Incongruent condition, but they did have greater Congruent activation than Older adults in the right medial frontal gyrus, right middle temporal gyrus, and left postcentral gyrus.

Neurolmage, Vol 21, No. 1 (January 2004): pg. 192-200. DOI. This article is (C) Elsevier and permission has been granted for this version to appear in e-Publications@Marquette. Elsevier does not grant permission for this article to be further copied/distributed or hosted elsewhere without the express permission from Elsevier. 
Table 4. Significant clusters for younger and older adults-incongruentcongruent comparison

Hemisphere/ Lobe Location BA $\begin{gathered}\text { Volume } \\ \left(\mathrm{mm}^{3}\right)\end{gathered}$ RL AP IS OC $t$ Result

Right/

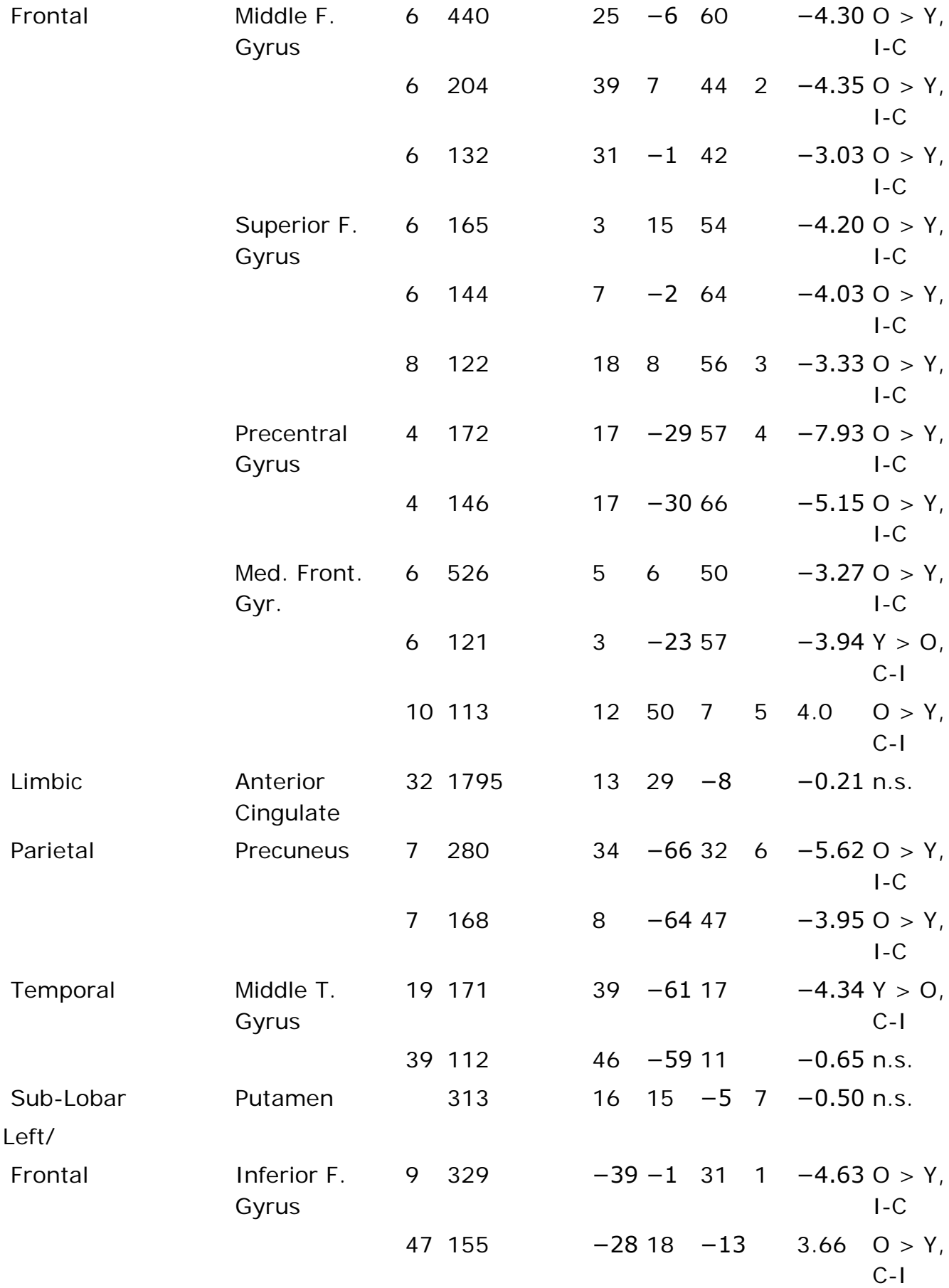

Neurolmage, Vol 21, No. 1 (January 2004): pg. 192-200. DOI. This article is (c) Elsevier and permission has been granted for this version to appear in e-Publications@Marquette. Elsevier does not grant permission for this article to be further copied/distributed or hosted elsewhere without the express permission from Elsevier. 
NOT THE PUBLISHED VERSION; this is the author's final, peer-reviewed manuscript. The published version may be accessed by following the link in the citation at the bottom of the page.

\begin{tabular}{|c|c|c|c|c|c|c|c|c|}
\hline Hemisphere/ Lobe & Location & BA & $\begin{array}{l}\text { Volume } \\
\left(\mathrm{mm}^{3}\right)\end{array}$ & $\mathbf{R} \mathbf{L}$ & AP & IS OC & $\mathbf{t}$ & Result \\
\hline Parietal & $\begin{array}{l}\text { Postcentral } \\
\text { Gyrus }\end{array}$ & 3 & 116 & -21 & -34 & 63 & -6.80 & $\begin{array}{c}O Y>0, \\
C-I\end{array}$ \\
\hline Temporal & Uncus & 36 & 138 & -19 & 0 & -31 & 4.51 & $\begin{array}{l}O>Y, \\
C-1\end{array}$ \\
\hline Sub-Lobar & Caudate Body & & 138 & -8 & 7 & 19 & 1.31 & n.s. \\
\hline
\end{tabular}

$\mathrm{BA}=$ Brodmann area, $\mathrm{RL}=$ right to left, $\mathrm{AP}=$ anterior to posterior, and IS $=$ inferior to superior via Talairach and Tournoux (1988). OC = overlapping I-C/I-N clusters; see also Fig. 1.

\section{I-N comparison}

Clusters of significant activation for the I- $\mathrm{N}$ comparison are presented in Table 5 . This additional analysis was included to narrow those areas that are active for interference that are less dependent upon the type of subtraction comparison. In other words, finding similar patterns and clusters in both I-C and I- $\mathrm{N}$ comparisons is an internal replication condition to validate areas important for inhibition. As with the I-C comparison, older adults exhibited relatively greater activation compared to younger adults in 11 clusters, 8 of which were in the frontal lobes, including areas very comparable to those in the I$\mathrm{C}$ comparison. Indeed, one cluster in left inferior frontal gyrus specifically overlaps with one in the I-C comparison. Also comparable to I-C, Young adults had greater activation in the Neutral condition in five clusters.

Table 5. Significant clusters for younger and older adults-incongruentneutral comparison

\begin{tabular}{|c|c|c|c|c|c|c|c|c|c|}
\hline Hemisphere/ Lobe & Location & BA & $\begin{array}{l}\text { Volume } \\
\left(\mathrm{mm}^{3}\right)\end{array}$ & $\mathbf{R} \mathbf{L}$ & $\mathbf{A P}$ & is & OC & $\mathbf{t}$ & Result \\
\hline \multicolumn{10}{|l|}{ Right/ } \\
\hline \multirow[t]{6}{*}{ Frontal } & Inferior F. Gyrus & 47 & 120 & 30 & 30 & -12 & & -4.13 & $\begin{array}{l}3 \mathrm{O}>\mathrm{Y} \\
\mathrm{I}-\mathrm{N}\end{array}$ \\
\hline & Middle F. Gyrus & 6 & 295 & 43 & 10 & 42 & 2 & -5.08 & $\begin{array}{c}8 \mathrm{O}>\mathrm{Y}, \\
\mathrm{I}-\mathrm{N}\end{array}$ \\
\hline & & 8 & 142 & 26 & 24 & 46 & & -4.18 & $\begin{array}{c}8 \mathrm{Y}>0, \\
\mathrm{~N}-\mathrm{I}\end{array}$ \\
\hline & Superior F. Gyrus & 6 & 138 & 25 & 9 & 55 & 3 & -2.94 & $\begin{array}{l}4 \mathrm{O}>\mathrm{Y}, \\
\mathrm{I}-\mathrm{N}\end{array}$ \\
\hline & Precentral Gyrus & 4 & 110 & 17 & -28 & 55 & 4 & -5.12 & $\begin{array}{l}2 \mathrm{O}>\mathrm{Y}, \\
\mathrm{I}-\mathrm{N}\end{array}$ \\
\hline & Medial F. Gyrus & 10 & 175 & 15 & 52 & 12 & 5 & -0.93 & 3 n.s. \\
\hline Limbic & Anterior Cingulate & 32 & 389 & 6 & 39 & -1 & & -2.05 & 5 n.s. \\
\hline
\end{tabular}

Neurolmage, Vol 21, No. 1 (January 2004): pg. 192-200. DOI. This article is (C) Elsevier and permission has been granted for this version to appear in e-Publications@Marquette. Elsevier does not grant permission for this article to be further copied/distributed or hosted elsewhere without the express permission from Elsevier. 


\begin{tabular}{|c|c|c|c|c|c|c|c|c|c|}
\hline \multirow[t]{3}{*}{ Hemisphere/ Lobe } & Location & BA & $\begin{array}{l}\text { Volume } \\
\left(\mathrm{mm}^{3}\right)\end{array}$ & $\mathbf{R L}$ & AP & IS & OC & $\mathbf{t}$ & Result \\
\hline & & 32 & 210 & 3 & 45 & 9 & & -3.23 & $\begin{array}{l}3 \mathrm{Y}>\mathrm{O}, \\
\mathrm{N}-\mathrm{I}\end{array}$ \\
\hline & Posterior Cingulate & 31 & 199 & 6 & -52 & 28 & & -2.90 & $\begin{array}{l}Y>O, \\
N-1\end{array}$ \\
\hline \multirow[t]{3}{*}{ Parietal } & Inferior P. Lobule & 40 & 115 & 46 & -45 & 26 & & -4.54 & $\begin{array}{l}+\mathrm{O}>\mathrm{Y}, \\
\mathrm{I}-\mathrm{N}\end{array}$ \\
\hline & & 40 & 109 & 59 & -22 & 20 & & -3.12 & $\begin{array}{l}2 \mathrm{Y}>\mathrm{O}, \\
\mathrm{N}-\mathrm{I}\end{array}$ \\
\hline & Precuneus & 39 & 322 & 34 & -66 & 34 & 6 & -4.55 & $\begin{array}{l}5 \mathrm{O}>\mathrm{Y}, \\
\mathrm{I}-\mathrm{N}\end{array}$ \\
\hline $\begin{array}{l}\text { Sub-Lobar } \\
\text { Left/ }\end{array}$ & Putamen/Thalamus & & 1279 & 14 & 15 & -7 & 7 & -1.09 & n.s. \\
\hline \multirow[t]{3}{*}{ Frontal } & Inferior F. Gyrus & $6 / 9$ & 153 & -40 & & 32 & 1 & -3.25 & $\begin{array}{l}5 \mathrm{O}>\mathrm{Y}, \\
\mathrm{I}-\mathrm{N}\end{array}$ \\
\hline & Precentral Gyrus & 4 & 177 & -22 & -19 & 63 & & -5.22 & $\begin{array}{l}2 \mathrm{O}>\mathrm{Y}, \\
\mathrm{I}-\mathrm{N}\end{array}$ \\
\hline & & 6 & 116 & -43 & -4 & 47 & & -4.60 & $\begin{array}{l}\mathrm{O}>\mathrm{Y}, \\
\mathrm{I}-\mathrm{N}\end{array}$ \\
\hline \multirow[t]{4}{*}{ Limbic } & Anterior Cingulate & 25 & 112 & -4 & 16 & -9 & & 3.33 & $\begin{array}{l}\mathrm{O}>\mathrm{Y}, \\
\mathrm{N}-\mathrm{I}\end{array}$ \\
\hline & & 24 & 127 & -2 & -15 & 34 & & -3.35 & $\begin{array}{c}5>0, \\
N-I\end{array}$ \\
\hline & Posterior Cingulate & 31 & 227 & 0 & -43 & 34 & & -3.45 & $\begin{array}{c}\mathrm{Y}>\mathrm{O}, \\
\mathrm{N}-\mathrm{I}\end{array}$ \\
\hline & & 23 & 127 & -5 & -58 & 21 & & -2.65 & n.s. \\
\hline \multirow[t]{2}{*}{ Parietal } & Inferior P. Lobule & 40 & 322 & -51 & -25 & 15 & & -1.76 & 5 n.s. \\
\hline & Precuneus & 7 & 237 & -23 & -63 & 34 & & -2.59 & n.s. \\
\hline \multirow[t]{3}{*}{ Sub-Lobar } & Putamen & & 223 & -15 & 20 & -9 & & 1.16 & n.s. \\
\hline & Claustrum & 13 & 215 & -34 & -17 & 4 & & -4.31 & $\begin{array}{l}1 O>Y, \\
I-N\end{array}$ \\
\hline & Thalamus, LPN & & 120 & -14 & -19 & 14 & & -1.10 & n.s. \\
\hline
\end{tabular}

$\mathrm{BA}=$ Brodmann area; $\mathrm{LPN}=$ lateral posterior nucleus; $\mathrm{RL}=$ right to left, $\mathrm{AP}=$ anterior to posterior, and IS = inferior to superior via Talairach and Tournoux (1988). OC = overlapping I-C/I-N clusters; see also Fig. 1.

A montage of $\mathrm{C}-\mathrm{N}, \mathrm{I}-\mathrm{C}, \mathrm{I}-\mathrm{N}$ comparisons are shown in Fig. 1, along with the clusters in the $\mathrm{I}-\mathrm{C}$ and $\mathrm{I}-\mathrm{N}$ comparisons that were more active in Older adults (Panel $\mathrm{C}$ ). The $\mathrm{I}-\mathrm{C} / \mathrm{I}-\mathrm{N}$ combined picture can help to clarify the neural bases of interference resolution because the two conditions are nearly identical. Two clusters, located in the left inferior frontal and right middle frontal gyri, demonstrated direct overlap and five clusters in the right hemisphere (superior, medial, and precentral frontal gyri; precuneus; putamen) were located in quite comparable locations in the combined picture. Five of these seven clusters, with 
NOT THE PUBLISHED VERSION; this is the author's final, peer-reviewed manuscript. The published version may be accessed by following the link in the citation at the bottom of the page.

the exception of those in the putamen and one in the right medial frontal gyrus, had greater relative activation in the Incongruent condition for Older adults.
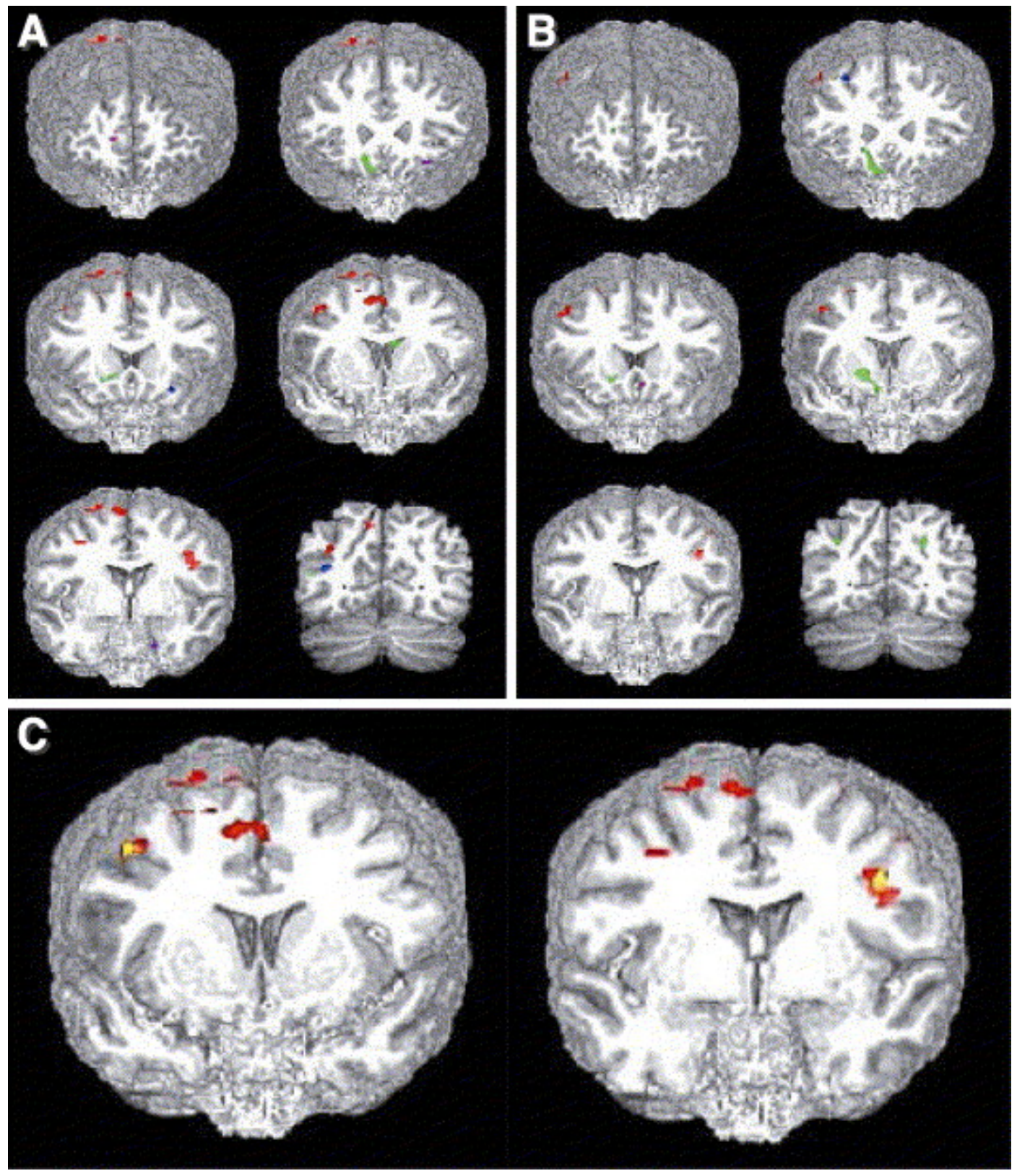

Fig. 1. Resulting clusters from the subtraction analyses amongst conditions where Incongruent $=\mathrm{I}$, Congruent $=\mathrm{C}$, and Neutral $=\mathrm{N}$. Sections are in radiologic orientation (left is right) and locations for Panels A and B (left to right by row) are 50, $23,15,7,-1$, and $-63 \mathrm{~mm}$ from the anterior commissure (negative = posterior); for Panel C, sections are 7 and $-1 \mathrm{~mm}$ from the anterior commissure. (Panel A) The I-C comparison, where red clusters represent greater I activation for older adults; purple clusters represent greater $\mathrm{C}$ activation for older adults; blue clusters represent greater

Neurolmage, Vol 21, No. 1 (January 2004): pg. 192-200. DOI. This article is (C) Elsevier and permission has been granted for this version to appear in e-Publications@Marquette. Elsevier does not grant permission for this article to be further copied/distributed or hosted elsewhere without the express permission from Elsevier. 
NOT THE PUBLISHED VERSION; this is the author's final, peer-reviewed manuscript. The published version may be accessed by following the link in the citation at the bottom of the page.

$\mathrm{C}$ activation for younger adults; and green clusters represent significant activation areas that were not statistically different between groups. (Panel B) The I-N comparison uses the color scheme described for Panel A (substituting $\mathrm{N}$ for $\mathrm{C}$ ). (Panel C) All clusters where older adults had I > C or N activation (red; yellow $=\mathrm{I}-\mathrm{C}$ and $\mathrm{I}-\mathrm{N}$ clusters overlapped).

\section{Discussion}

The purpose of the current study was to examine the functional neuroanatomy of Stroop interference and to examine age-related differences associated with it. As was predicted, older adults exhibited greater interference-related activation relative to younger adults in left inferior frontal gyrus. This occurred in both the I- $\mathrm{N}$ and I-C comparisons. Indeed, a comparison of these two conditions showed direct spatial overlap of this cluster (Fig. 1, panel C). Importantly, activation was present in this cluster for both participant groups, but the magnitude was greater for older participants. The importance of the inferior frontal gyri in inhibitory control has been shown in several previous studies (Aron et al., 2003; Garavan et al., 1999; Konishi et al., 1998a, 1999). The finding of increased activation in this region in older adults is consistent with our previous study using a go/no-go task (Nielson et al., 2002) and with another Stroop study (Milham et al., in press), although it contrasts with findings of Lonides et al. (2000) who reported greater young relative to old activation here in a verbal working memory paradigm. Although the J onides study would seem to conflict, it is quite a different task, albeit including an inhibitory component, and their findings are consistent with the existing memory literature.

Because the current study did not use an event-related design, it could be argued that greater activation for older adults in the left inferior frontal gyrus is related to their greater number of errors rather than to recruitment to aid in successful performance. Indeed, the fourbutton box used in this study was, by report and performance, more difficult for older than younger adults to use. However, all subjects performed well ( $>80 \%$ correct average) and older adults exhibited more errors overall rather than for any specific condition. Furthermore, because both subtraction comparisons (I-C, I-N) were used, the increased activation cannot be attributed to either the Congruent or Neutral conditions. Thus, these conditions acted as controls for all aspects of the task except for interference resolution. As such, the

Neurolmage, Vol 21, No. 1 (January 2004): pg. 192-200. DOI. This article is (C) Elsevier and permission has been granted for this version to appear in e-Publications@Marquette. Elsevier does not grant permission for this article to be further copied/distributed or hosted elsewhere without the express permission from Elsevier. 
increased activation is likely due to resolution of interference, rather than to errors. Indeed, younger adults also had greater Incongruent activation relative to Congruent and Neutral conditions in this area (although of lesser magnitude than for older adults), thus verifying the importance of this region in resolving interference. The betweengroups overlap in regional activation would also suggest that the slight difference in image acquisition parameters between groups was not responsible for the results. Moreover, the present findings are consistent with brain lesion literature (Perret, 1974; Pujol et al., 2001; Vendrell et al., 1995) and brain imaging literature with younger adults using the Stroop paradigm (e.g., Bench et al., 1993; Brown et al., 1999; George et al., 1994, 1997; Mead et al., 2002; Taylor et al., 1997).

A second hypothesis of the current study was that there would be diffuse areas of increased activation in older adults. Indeed, older adults had greater relative activation compared to younger adults in premotor, dorsolateral, ventrolateral, and medial frontal areas, underlining the importance of the frontal lobes to this task, and by comparison with previous research, to differences in brain functioning in older adults. Of the 22 clusters in the I-C comparison, 11 were greater in older adults and 9 of these were located in the frontal lobes. Similarly for the I-N comparison, 11 of 24 clusters were greater in older adults, 8 of which were in the frontal lobes. The few clusters of greater activation for younger adults were all of relatively greater magnitude in the respective control conditions.

When comparing the other cluster combinations that were significantly more active in older adults to the two other published studies of inhibition and Stroop performance that included older adults, some similarities are evident. The right middle frontal gyrus combination (cluster 2) and the right precuneus combination (cluster 6) were similar in location to clusters reported in the study by Nielson et al. (2002), although neither was significantly different between younger and older adults in that study. The precuneus cluster also compares to one reported by Milham et al. (in press), which was not different between groups. The finding in the right superior frontal gyrus cluster (cluster 3 ) located in pre-SMA, was similar to the study by Nielson et al. (2002) in both location and direction of effect. This cluster was also similar in location to several clusters reported by

Neurolmage, Vol 21, No. 1 (January 2004): pg. 192-200. DOI. This article is (c) Elsevier and permission has been granted for this version to appear in e-Publications@Marquette. Elsevier does not grant permission for this article to be further copied/distributed or hosted elsewhere without the express permission from Elsevier. 
Milham et al. (in press), but it was more comparable to findings from their congruent (competition) condition, where activation differences between old and young were not found. Thus, the inferior and middle frontal gyri, pre-SMA, and precuneus appear to be parts of an inhibitory circuit, which is supported by an extensive literature (Garavan et al., 1999; Konishi et al., 1998a, b, 1999; Rubia et al., 2001), and are important for examining age-related functional differences (DiGirolamo et al., 2001; Milham et al., in press; Nielson et al., 2002).

Despite the greater young activation in dorsal lateral prefrontal areas reported by Milham et al. (in press), there were no areas of significantly greater interference-related activation for younger adults in the present study. There are several possible reasons for this lack of similarity. The most likely reason is variation in subject characteristics (e.g., age, educational attainment, which often affects aging studies), imaging and analysis methods, and task design (for a review, see Cabeza and Nyberg, 2000). Studies of the Stroop task are also known to differ based on the characteristics of the control condition (e.g., Bench et al., 1993; Brown et al., 1999; George et al., 1994, 1997; Mead et al., 2002; Taylor et al., 1997). I mportantly, the Milham study may have been more difficult than the present task because they interspersed Neutral trials in both Congruent and Incongruent blocks. Indeed, although our analyses show a significant effect of interference in the task, comparing the amounts of interference in the present study (see Table 2) with their results showed that Milham et al. (in press) achieved a greater degree of interference (although not between-groups) than did our task. Moreover, the behavioral analyses in the current study show that sufficient interference (i.e., difficulty) was achieved in both participant groups and although the small samples limited power, older adults had marginally greater interference than younger subjects did. As such, the Milham approach might actually have made the control condition more difficult. A closer look at their functional data showed that there are more foci of activation in the congruent condition ("competition") than in the incongruent condition ("conflict"). Thus, task-switching demands could explain the larger number and greater extent of activation in their study, which could explain differences with the present study as well. Bandettini and colleagues have highlighted the benefits of using simpler task designs in $\mathrm{FMRI}$ and PET studies (where sample sizes are

Neurolmage, Vol 21, No. 1 (January 2004): pg. 192-200. DOI. This article is (c) Elsevier and permission has been granted for this version to appear in e-Publications@Marquette. Elsevier does not grant permission for this article to be further copied/distributed or hosted elsewhere without the express permission from Elsevier. 
small and functional activation has poor temporal resolution) toward understanding functional neuroanatomy (Bandettini and Wong, 1997; Bandettini et al., 1992).

In conclusion, the results showed comparable activation regions generally in young and older adults in a Stroop task, with a variety of predominantly prefrontal regions, having greater activation magnitude during interference in older adults. That is, older adults appeared to use multiple frontal regions to a greater degree than young adults. The left inferior gyrus was particularly important to performance on this task. The findings are consistent with the proposal that older adults recruit additional, particularly prefrontal, areas during task performance (e.g., Cabeza, 2002; DiGirolamo et al., 2001; Madden et al., 1997; Nielson et al., 2002). One recent memory study reported that the inferior frontal region is activated non-specifically by older adults (Logan et al., 2002), but an inhibition study (Nielson et al., 2002), more comparable to the current study, showed that activation of this region was both task-specific and supportive of successful task performance for those who found the task most difficult (i.e., poorer performers). Although this would seem to contrast with memory studies reporting increased activation in better performing elders (Cabeza et al., 2002; Rosen et al., 2002), the difference could be due to the type of task or that the Nielson et al. (2002) study examined only successfully performed trials. Thus, the poorest performers had the greatest activation when they performed correctly (well). Regardless, the task-specific recruitment of prefrontal regions in the current study, particularly left inferior frontal gyrus, replicates previous findings using two different inhibitory tasks (Milham et al., in press; Nielson et al., 2002), suggesting that recruitment of this region by elders is generalizable across inhibitory paradigms.

Future studies can build upon these findings, and distinguish amongst study differences, perhaps by separately analyzing the functional activation associated with correct and incorrect responses and by parametrically manipulating task difficulty. By using this strategy, it may be possible to determine more clearly when, in whom, and under what conditions recruitment occurs. For example, it would be very valuable to know whether recruitment is an age-related phenomenon, or whether it is a universal form of compensation that

Neurolmage, Vol 21, No. 1 (January 2004): pg. 192-200. DOI. This article is @ Elsevier and permission has been granted for this version to appear in e-Publications@Marquette. Elsevier does not grant permission for this article to be further copied/distributed or hosted elsewhere without the express permission from Elsevier. 
NOT THE PUBLISHED VERSION; this is the author's final, peer-reviewed manuscript. The published version may be accessed by following the link in the citation at the bottom of the page.

can occur even in younger adults under conditions of high task difficulty.

\section{Acknowledgements}

The authors acknowledge the assistance of Kirk I. Erickson with data collection, and Andrew R. Mayer for the data analysis technique. This work was supported by the Foley Center for Aging and Development, Medical College of Wisconsin, Milwaukee, WI, USA.

\section{References}

Aron et al., 2003. A.R. Aron, P.C. Fletcher, E.T. Bullmore, B.J. Sahakian, T.W. Robbins. Stop-signal inhibition disrupted by damage to right inferior frontal gyrus in humans. Nat. Neurosci., 6 (2) (2003), pp. 115-116

Bandettini and Wong, 1997. P.A. Bandettini, E.C. Wong. Magnetic resonance imaging of human brain function: principles, practicalities, and possibilities. Funct. Imaging, 8 (1997), pp. 345-372

Bandettini et al., 1992. P. Bandettini, E. Wong, R. Hinks, R. Tikofsky, J. Hyde. Time course EPI of human brain function during task activation. Magn. Reson. Med., 30 (1992), pp. 161-173

Banich et al., 2000. M. Banich, M. Milham, N.J . Cohen, T. Wszalek, A. Kramer, Z.-P. Liang, D. Gullet, C. Shah, C. Brown. Prefrontal regions play a predominant role in imposing an attentional "set:" evidence from fMRI. Cogn. Brain Res., 10 (2000), pp. 1-9

Barkley, 1997. R.A. Barkley. Behavioral inhibition, sustained attention and executive functions: constructing a unifying theory of ADHD. Psychol. Bull., 121 (1997), pp. 65-94

Bench et al., 1993. C. Bench, C. Frith, P. Grasby, K. Friston, E. Paulesu, R. Frackowiak, R. Dolan. Investigations of the functional anatomy of attention using the Stroop task. Neuropsychologia, 31 (1993), pp. 907-922

Brown et al., 1999. G.G. Brown, S.S. Kindermann, G.J. Siegle, E. Granholm, E.C. Wong, R.B. Buxton. Brain activation and pupil response during covert performance of the Stroop Color Word task. J. Int. Neuropsychol. Soc., 5 (4) (1999), pp. 308-319

Buckner et al., 2000. R. Buckner, J. Logan, D. Donaldson, M. Wheeler. Functional brain imaging of young, nondemented, and demented older adults. J. Cogn. Neurosci., 12 (Suppl. 2) (2000), pp. 24-34

Cabeza, 2002. R. Cabeza. Hemispheric asymmetry reduction in older adults: the HAROLD model. Psychol. Aging, 17 (2002), pp. 85-100

Neurolmage, Vol 21, No. 1 (January 2004): pg. 192-200. DOI. This article is (C) Elsevier and permission has been granted for this version to appear in e-Publications@Marquette. Elsevier does not grant permission for this article to be further copied/distributed or hosted elsewhere without the express permission from Elsevier. 
NOT THE PUBLISHED VERSION; this is the author's final, peer-reviewed manuscript. The published version may be

accessed by following the link in the citation at the bottom of the page.

Cabeza and Nyberg, 2000. R. Cabeza, L. Nyberg. Imaging cognition II: an empirical review of 275 PET and fMRI studies. J. Cogn. Neurosci., 12 (1) (2000), pp. 1-47

Cabeza et al., 1997. R. Cabeza, C. Grady, L. Nyberg, A. Mclntosh, E. Tulving, S. Kapur, J. Jennings, S. Houle, F.I.M. Craik. Age-related differences in neural activity during memory encoding and retrieval: a positron emission tomography study. J. Neurosci., 17 (1) (1997), pp. 391-400

Cabeza et al., 2002. R. Cabeza, N.D. Anderson, J.K. Locantore, A.R. Mclntosh. Aging gracefully: compensatory brain activity in highperforming older adults. Neurolmage, 13 (2002), pp. 1302-1394

Carter et al., 1995. C. Carter, P. Krener, M. Chaderjan, C. Northcutt. Asymmetrical visual-spatial attentional performance in ADHD: evidence for a right hemispheric deficit. Biol. Psychiatry, 37 (1995), pp. 789-797

Cohen et al., 1984. N. Cohen, R. Dustman, D. Bradford. Age related decrements in Stroop color test performance. J. Clin. Psychol., 40 (1984), pp. 1244-1250

Cox, 1996. R. Cox. AFNI: software for analysis and visualization of functional magnetic resonance neuroimages. Comput. Biomed. Res., 29 (1996), pp. 162-173

DiGirolamo et al., 2001. G.J . DiGirolamo, A.F. Kramer, V. Barad, N.J . Cepeda, D.H. Weissman, M.P. Milham, T.M. Wszalek, N.J . Cohen, M.T. Banich, A. Webb, A.V. Belopolsky, E. McAuley. General and task-specific frontal lobe recruitment in older adults during executive processes: a fMRI investigation of task-switching. NeuroReport, 12 (9) (2001), pp. 2065-2071

Folstein et al., 1975. M.F. Folstein, S.E. Folstein, P.R. McHugh. “Mini-mental state". A practical method for grading the cognitive state of patients for the clinician. J. Psychiatr. Res., 12 (3) (1975), pp. 189-198

Garavan et al., 1999. H. Garavan, T.J. Ross, E. A. Stein. Right hemispheric dominance of inhibitory control: an event-related fMRI study. Proc. Natl. Acad. Sci., 96 (1999), pp. 8301-8306

George et al., 1994. M.S. George, T.A. Ketter, P.I. Parekh, N. Rosinsky, H. Ring, B.J . Casey, M.R. Trimble, B. Horwitz, P. Herscovitch, R.M. Post. Regional brain activity when selecting a response despite interference: an $\mathrm{H}_{2}{ }^{15} \mathrm{O}$ PET study of the Stroop and an emotional Stroop. Hum. Brain Mapp., 1 (1994), pp. 194-209

George et al., 1997. M. George, T. Ketter, P. Parekh, N. Rosinsky, H. Ring, P. Pazzaglia, L. Marangell, A. Callahan, R. Post. Blunted left cingulate activation in mood disorder subjects during a response interference task (Stroop). J. Neuropsychiatry Clin. Neurosci., 9 (1) (1997), pp. 5563

Neurolmage, Vol 21, No. 1 (January 2004): pg. 192-200. DOI. This article is @ Elsevier and permission has been granted for this version to appear in e-Publications@Marquette. Elsevier does not grant permission for this article to be further copied/distributed or hosted elsewhere without the express permission from Elsevier. 
Grady et al., 1994. C.L. Grady, J.M. Maisog, B. Horwitz, L. G. Ungerleider, M.J . Mentis, J.A. Salerno, P. Pietrini, E. Wagner, J.V. Haxby. Age-related changes in cortical blood flow activation during visual processing of faces and location. J. Neurosci., 14 (1994), pp. 1450-1462

Grady et al., 1995. C.L. Grady, A.R. Mcl ntosh, B. Horwitz, J.M. Maisog, L.G. Ungerleider, M.J. Mentis, P. Pietrini, M.B. Schapiro, J.V. Haxby. Agerelated reductions in human recognition memory due to impaired encoding. Science, 269 (1995), pp. 218-221

Hasher and Zacks, 1988. L. Hasher, R. Zacks. Working memory, comprehension and aging: a review and a new view. Psychol. Learn. Motiv., 22 (1988), pp. 193-225

Hasher et al., 1999. L. Hasher, R. Zacks, C. May. Inhibitory control, circadian arousal, and age. D. Gopher, A. Koirat (Eds.), Attention and Performance, vol. XVII, MIT Press, Cambridge, MA (1999), pp. 653675

Huettel et al., 2001. S. Huettel, J. Singerman, G. McCarthy. The effects of aging upon the hemodynamic response measured by functional MRI. Neurolmage, 13 (2001), pp. 161-175

Lonides et al., 2000. J. Jonides, C. Marshuetz, E. E. Smith, P. Reuter-Lorenz, R.A. Koeppe, A. Hartley. Age differences in behavior and PET activation reveal differences in interference resolution in verbal working memory. J. Cogn. Neurosci., 12 (1) (2000), pp. 188-196 Kahneman and Chajczyk, 1983. D. Kahneman, D. Chajczyk. Tests of the automaticity of reading: dilution of Stroop effects by color-irrelevant stimuli. J. Exp. Psychol. Hum. Percept. Perform., 9 (1983), pp. 497509

Konishi et al., 1998a. S. Konishi, K. Nakagima, I. Uchida, K. Sekihara, Y. Miyashita. No-Go dominant brain activity in human inferior prefrontal cortex revealed by functional magnetic resonance imaging. Eur. J . Neurosci., 10 (1998), pp. 1209-1213

Konishi et al., 1998b. S. Konishi, K. Nakajima, I. Uchida, M. Kameyama, K. Nakahara, K. Sekihara, Y. Miyashita. Transient activation of inferior prefrontal cortex during cognitive set shifting. Nat. Neurosci., 1 (1) (1998), pp. 80-84

Konishi et al., 1999. S. Konishi, K. Nakajima, I. Uchida, H. Kikyo, M.

Kameyama, Y. Miyashita. Common inhibitory mechanism in human inferior prefrontal cortex revealed by event-related functional MRI. Brain, 122 (1999), pp. 981-991

Kramer et al., 1994. A. Kramer, D. Humphrey, J. Latish, G. Logan, D. Strayer. Aging and inhibition: beyond a unitary view of inhibitory processing in attention. Psychol. Aging, 9 (1994), pp. 491-512

Logan, 1980. G. Logan. Attention and automaticity in Stroop and priming tasks: theory and data. Cogn. Psychol., 12 (1980), pp. 523-553

Neurolmage, Vol 21, No. 1 (January 2004): pg. 192-200. DOI. This article is (C) Elsevier and permission has been granted for this version to appear in e-Publications@Marquette. Elsevier does not grant permission for this article to be further copied/distributed or hosted elsewhere without the express permission from Elsevier. 
NOT THE PUBLISHED VERSION; this is the author's final, peer-reviewed manuscript. The published version may be

accessed by following the link in the citation at the bottom of the page.

Logan et al., 2002. J.M. Logan, A.L. Sanders, A.Z. Snyder, J.C. Morris, R.L. Buckner. Under-recruitment and nonselective recruitment: dissociable neural mechanisms associated with aging. Neuron, 33 (2002), pp. 827-840

Madden and Hoffman, 1997. D.J. Madden, J.M. Hoffman. Application of positron emission tomography to age-related cognitive changes. K.R.R. Krishman, P.M. Doraiswamy (Eds.), Brain Imaging in Clinical Psychiatry, M. Dekker, New York, NY (1997), pp. 576-601

Madden et al., 1997. D.J. Madden, T.G. Turkington, J.M. Provenzale, T.C. Hawk, J.M. Hoffman, R.E. Coleman. Selective and divided visual attention: age-related changes in regional cerebral blood flow measured by M2150 PET. Hum. Brain Mapp., 5 (1997), pp. 389-409

Madden et al., 1999. D. Madden, T. Turkington, J. Provenzale, L. Denny, T. Hawk, L. Gottlob, R. Coleman. Adult age differences in the functional neuroanatomy of verbal recognition memory. Hum. Brain Mapp., 7 (1999), pp. 115-135

Mead et al., 2002. L. Mead, A. Mayer, J. Bobholtz, S. Woodley, J. Cunningham, T. Hammeke, S. Rao. Neural basis of the Stroop interference task: response competition or selective attention. J. Int. Neuropsychol. Soc., 8 (2002), pp. 735-742

Milham et al., 2002. M. Milham, K.I. Erickson, M. Banich, A. Kramer, A. Webb, T. Wszalek, N. Cohen. Attentional control in the aging brain: insights from an fMRI study of the Stroop task. Brain Cogn., 49 (3) (2002), pp. 277-296

Nielson et al., 2002. K.A. Nielson, S.A. Langenecker, H. Garavan. Differences in the functional neuroanatomy of inhibitory control across the adult lifespan. Psychol. Aging, 17 (1) (2002), pp. 56-71

Oldfield, 1971. R.C. Oldfield. The assessment and analysis of handedness: the Edinburgh inventory. Neuropsychologia, 9 (1971), pp. 97-113

Pardo et al., 1990. D. Pardo, P. Pardo, K. Janer, M. Raichle. The anterior cingulate cortex mediates processing selection in the Stroop attentional control paradigm. Proc. Natl. Acad. Sci. U. S. A., 87 (1990), pp. 256-259

Perret, 1974. E. Perret. The left frontal lobe of man and the suppression of habitual responses in verbal categorical behavior. Neuropsychologia, 12 (3) (1974), pp. 323-330

Pujol et al., 2001. J. Pujol, P. Vendrell, J. Deus, C. Junque, J. Bello, J. MartiVilalta, A. Capdevila. The effect of medial frontal and posterior parietal demyelinating lesions in Stroop interference. Neurol mage, 13 (2001), pp. 68-75

Rosen et al., 2002. A.C. Rosen, M.W. Prull, R. O'Hara, E.A. Race, J.E. Desmond, G.H. Glover, J.A. Yesavage, J.D. Gabrieli. Variable effects of

Neurolmage, Vol 21, No. 1 (January 2004): pg. 192-200. DOI. This article is @ Elsevier and permission has been granted for this version to appear in e-Publications@Marquette. Elsevier does not grant permission for this article to be further copied/distributed or hosted elsewhere without the express permission from Elsevier. 
aging on frontal lobe contributions to memory. NeuroReport, 13 (18) (2002), pp. 2425-2428

Rubia et al., 2001. K. Rubia, T. Russell, S. Overmeyer, M. Brammer, E. Bullmore, T. Sharma, A. Simmons, S. Williams, V. Giampietro, C. Andrew, E. Taylor. Mapping motor inhibition: conjunctive brain activations across different versions of the go/no-go and stop tasks. Neurolmage, 13 (2001), pp. 250-261

Rypma and D'Esposito, 2000. B. Rypma, M. D'Esposito. Isolating the neural mechanisms of age-related changes in human working memory. Nat. Neurosci., 3 (5) (2000), pp. 509-515

Sheikh and Yesavage, 1986. J.I. Sheikh, J.A. Yesavage. Geriatric Depression Scale (GDS) : recent evidence and development of a shorter version. Clin. Gerontol., 15 (1-2) (1986), pp. 165-173

Stroop, 1935. J. Stroop. Studies of interference in serial verbal interactions. J. Exp. Psychol., 18 (1935), pp. 643-662

Talairach and Tournoux, 1988. J. Talairach, P. Tournoux. Co-Planar Stereotaxic Atlas of the Human Brain. Thieme, New York (1988) Taylor et al., 1997. S. Taylor, S. Kornblum, E. Lauber, S. Minoshima, R. Koeppe. Isolation of specific interference processing in the Stroop task: PET activation studies. Neurol mage, 6 (1997), pp. 81-92

Vendrell et al., 1995. P. Vendrell, C. Junque, J. Pujol, M. Jurado, J. Molets, J. Grafman. The role of prefrontal regions in the Stroop task.

Neuropsychologia, 33 (3) (1995), pp. 341-352

Ward et al., 1998. B. Ward, H. Garavan, T. Ross, A. Bloom, R. Cox, E. Stein. Nonlinear regression for fMRI time series analysis. Paper Presented at the 4th International Conference on Functional Mapping of the Human Brain, Montreal, Canada (1998)

West and Bell, 1997 R. West, M. Bell. Stroop color word interference and electroencephalogram activation evidence for age-related decline in the anterior attention system. Neuropsychology, 11 (1997), pp. 421427

Wong et al., 1992a. E. Wong, E. Buskamp, J. Hyde. A volume optimized quadrature elliptical endcap birdcage brain coil. Paper Presented at the 11th Annual Scientific Meeting, Society for Magnetic Resonance Medicine, Berlin, Germany (1992)

Wong et al., 1992b. E.C. Wong, P.S. Bandettini, J.S. Hyde. Echo-planar imaging of the human brain using a three axis local gradient coil. Proceedings of the Society for Magnetic Resonance Medicine (11th Meeting) (1992), p. 105

Zajano and Gorman, 1986. M. Zajano, A. Gorman. Stroop interference as a percentage of congruent items. Percept. Mot. Skills, 63 (1986), pp. 1087-1096

Neurolmage, Vol 21, No. 1 (January 2004): pg. 192-200. DOI. This article is @ Elsevier and permission has been granted for this version to appear in e-Publications@Marquette. Elsevier does not grant permission for this article to be further copied/distributed or hosted elsewhere without the express permission from Elsevier. 